\title{
Science teachers' perception and implementation of inquiry-based reform initiatives in relation to their beliefs and professional identity
}

\section{Hong, Ji}

Educational Psychology, University of Oklahoma,USA (jyhong@ou.edu)

Vargas, Penelope

School of Education, Clemson University, USA (pvargas@clemson.edu)

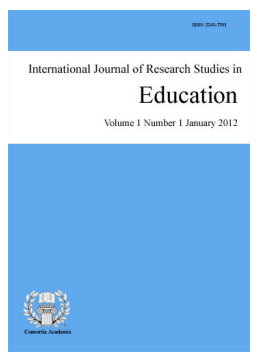

ISSN: $2243-7703$ Online ISSN: 2243-7711

OPEN ACCESS

\section{Abstract}

The purpose of this study was to understand how early career science teachers perceive and interpret the calls for inquiry-based instruction (as suggested by National Science Education Standards) in relation to their emerging professional identity and beliefs. Further, this study explored how the school and classroom contexts influenced teachers' implementation of the reform-based teaching practices. Using semi-structured interviews with twelve early career science teachers, this study revealed that teachers often showed limited understanding about inquiry-based instruction, such as hands-on lab activities, and devoted small amount of time for implementing inquiry teaching. However, interestingly, their beliefs about teaching science were aligned with the assumptions of inquiry-based instruction. The lack of inconsistency between beliefs and practices seem to result from the influence of contextual factors. School and classroom environments that limit teachers' agency and sense of power lead teachers to experience unpleasant emotions, which may eventually threaten their identity as a teacher. This paper ends with implications for school administrators and policy makers.

Keywords: inquiry-based instruction; science teacher identity; teacher beliefs; teacher development; teacher education 


\section{Science teachers' perception and implementation of inquiry-based reform initiatives in relation to their beliefs and professional identity}

\section{Introduction}

For science teachers, especially those who have entered the profession recently, one of the greatest emphases that dominates the culture of the teaching profession is inquiry-based instruction. Early on, inquiry-based instruction has been recommended by Benchmarks for Science Literacy (American Association for the Advancement of Science, 1993) and National Science Education Standards (National Research Council, 1996, 2011) in order to help students to develop into scientifically literate citizens. As one of the key concepts of the reform initiatives, science literacy is defined as the knowledge and understanding of scientific concepts and processes required for personal decision-making, participation in civic and cultural affairs, and economic productivity. Thus, scientifically literate students can understand scientific concepts and identify science related issues underlying national and local decisions (National Research Council, 1996, 2011). To increase science literacy, an inquiry classroom takes the more constructivist approach of allowing students to construct their own understanding of science through investigation, dialogue, and reflection.

The National Science Education Standards (NSES) and A Framework for K-12 Science Education (NRC, 2011) recommendations describe the inquiry-based classroom not just as a learning environment which focuses on hands-on experiments but as a setting which aims to foster understanding of the processes of doing science more deeply. The standards propose that through the method of inquiry, students will begin to learn how scientific understanding is reached. In this model, rather than information coming top-down from the teacher, students are encouraged to construct their own knowledge and understanding of science by posing probing questions and investigating them to find answers. This is a move away from teachers presenting decontextualized scientific knowledge; instead asking that teachers stimulate classroom questioning and investigation and encourage students not to rely on an external rational authority as to what constitutes scientific ‘truth' (Anderson, 2002; Minner, Levy, \& Century, 2010).

Widespread implementation of this reform agenda will require, for many teachers, the changing of instructional practices. At the forefront of these reform initiatives are changes in teaching practices where teachers are required to modify the ways they instruct, interact with their students and often to the curriculum they are teaching. Thus, it is essential for successful implementation of reform to recognize the critical role of teachers as partners, who must be at least minimally acquiescent to larger goals. Current research has studied reforms and related issues with the focus on individual teachers and their teaching lives (See for instance: Lasky, 2005; Lotter, Harwood, \& Bonner, 2007; Schmidt \& Datnow, 2005; Sloan, 2000; Sullivan, 2008). Examining individual teachers is essential because reform often involves teachers transitioning from teaching practices with which they are familiar to something new and different. Changing teaching practice is not a simple task for teachers. As teachers "make sense of their lives in a myriad of expressive, assertive, and goal-directed ways within the constraints imposed on them" (Mehan, Villanueva, Hubbard, \& Lintz, 1996, p. 19), it is difficult to adjust teaching practices to fit the demands of reform mandates without an accompanying psychological shift and modification of their sense of self as a teacher, which comes from adopting different roles and perspectives. One explanation for this difficulty was pointed out by Park and Oliver (2008), who showed that teacher professionalism is fashioned within the idiosyncratic approaches by which individual teachers enact their instructional practice. Thus, teachers will often feel that making a complete change in their instructional approach equates with a dismissal of their own existing beliefs, established professional identity, and teaching practices.

Several researchers have examined the psychological and sense-of-self issues and have identified teachers' professional identity as one of the most important factors relevant to the successful implementation of the reform 
agenda (Lasky, 2005; van Veen, Sleegers, \& van de Ven, 2005). Much of this research is grounded in the idea that 'self' is crucial in constructing the way we interact with the environment and make judgments in a given context. The way we perceive ourselves is influenced by the context we are situated, and this self-perception influences our choice of action and judgment. In addition, teachers' beliefs about teaching and learning are considered an important foundation for teachers' identify formation, identity mediation, and behavior (Korthagen, 2004; Van den Berg, 2002). Therefore, teachers' professional identity and corresponding beliefs cannot be separated (Kagan, 1992). Researchers in this area have also suggested that beliefs are often precursors to action, specifically with regard to teachers' pedagogical decisions (Pajares, 1992; Torff \& Warburton, 2005). Thus, without changing teachers' beliefs and identities concerning reform plans, teaching practices may only reflect surface level change.

Given the importance of teachers' professional identity and beliefs, we attempted to understand how science teachers' identity and beliefs are related to their inquiry-based instruction and professional practices, such as understanding and delivering the curriculum, making various decisions, and perceiving barriers or expectations in the context of reforms in Science Education.

\subsection{Teachers' Professional Identity}

Identity grew out of the concept that psychologists of the first half of the $20^{\text {th }}$ century called the "self." Early on, researchers conceptualized the self as a singular, fixed, stable, and decontextualized set of attributes that are fairly independent from the external environment (Allport, 1955; Cooley, 1902). However, these initial views were challenged, because they could not explain the diversity or changes in behavior depending on the context. More recently, researchers have conceptualized identity formation as a dynamic, continually changing, and active process which takes place over time through the interaction with others and environment (Cooper \& Olson, 1996; Johnson, 2003; Kelchtermans, 1993; Lemke 2003; Watson, 2006). That is, identity is continually being formed and reformed through the way we internalize aspects of the external environment, negotiate interactions, and externalize ourselves to others. Individuals, as active agents, have the ability to make choices and carry forth actions within a given context, and thus individuals can influence their lives and environment while at the same time they are shaped by social structures (Giddens, 1979). Giddens explained it as a "duality of structure". That is, structures both enable and constrain individual's agency.

For teachers, the most salient social structure would be their classroom and school environment where they interact with students, colleague teachers, parents, and administrators. Related to this conception of the duality of structures, several researchers have studied teacher identity in relation to their sense of power, vulnerability, agency, autonomy, and emotional engagement within the context of educational reform mandates (Day, 2002; Kelchtermans, 1996; Lasky, 2005; Lofty, 2006; Sloan, 2000; van Lier, 2007). These researchers concurred that when schools mediated the reform mandates under the assumption that teachers could be nudged into the shape that best fits what the schools need, it often resulted in the erosion of teachers' autonomy and challenged teachers' individual or collective identities. Also, teachers' emotional experiences, whether they are positive or negative, influence their self-perception, while self-perception and evaluation generate emotional reactions as well (Cross \& Hong, 2009). For example, a teacher evaluates whether the nature and meaning of a particular transaction are significant or not. If they are evaluated as something significant, then emotions are elicited depending on how well aligned the outcome of the transaction is with his or her goals and expectations (Fogel, 2001; Frijda, 2001; Harter, 1998; Hermans \& Hermans-Jansen, 2001).

\subsection{Teachers' Beliefs}

Teachers' beliefs are also an important psychological factor that is closely intertwined with their teaching practices, specifically related to the use of inquiry instruction. There are three main areas of teachers' beliefs that research has indicated have the greatest impact on classroom practice. Ernest (1989a, 1989b) stated that teachers' beliefs about teaching, learning, and the nature of the subject are the key beliefs in terms of a teachers' approach 
to instruction.

For science teachers, the nature of the subject they teach is more specifically referred to as their "nature of science' beliefs. The relationship between nature of science beliefs and teaching practice has been the subject of several research studies (e.g., Bryan, 2003; Eick \& Reed, 2002; Lederman, 1999; Lederman \& Zeidler, 1987; Tobin \& McRobbie, 1997; Trumbull, Scarano \& Bonney, 2006; Water-Adams, 2006). Research indicates that there is a relationship between teachers' beliefs about the nature of science and the teaching practices enacted in the classroom, although this may not be strictly linear and there may be other factors which influence this relationship (Lederman, 1999; Lederman \& Zeidler, 1987). In relation to the implementation of reform based practices, one core factor that may influence the relationship between beliefs and practice is the alignment between the underlying assumptions of the reform about what constitutes disciplined knowledge and effective teaching in science and those which the teachers themselves hold (Gregoire, 2003). Given that the National Standards-based reform is built on the assumption that science knowledge is constructed, it follows that teachers are more likely to implement the reform in the classroom when their underlying beliefs about the nature of science knowledge are aligned with those of the reform (Kang, 2008; Kang \& Wallace 2004; Tsai, 2006).

Without this alignment between teachers' beliefs about knowledge in science and effective way to teach science and the assumptions of the reform, teachers are unlikely to carry out inquiry-based instruction (Roehrig $\&$ Kruse, 2010). Therefore, for teachers whose beliefs are not aligned with those of the reform, conceptual change may be necessary if they are to implement inquiry-based instruction as intended by the reform mandates. However, research indicates that when teachers are presented with a reform agenda, which is not aligned with their beliefs, belief change is not guaranteed (Cross \& Hong, 2009; Ibrahim, Al-Kaabi, \& El-Zaatari, 2013; Romanowski \& Amatullah, 2014). There are several possible responses to the reform, including that teachers ignore the reform altogether or make only peripheral changes to their instruction while still not accepting the underlying assumptions of the reform (Gregoire, 2003). In this case, though the instruction may seem to the casual observer or even to the teacher themselves, as more "hands-on", or "inquiry-based", the lessons may still not encourage students to construct their own science knowledge in the ways demanded by the inquiry-based reforms.

It is important to note that it is not only the mismatch between teachers' assumptions about the nature of science knowledge and those of reform which may require belief change, but also the mismatch between teachers' beliefs about teaching and learning and those presented by reform mandates. Beliefs about teaching and learning include their beliefs about effective teaching strategies and evaluation of student learning (Kagan, 1992).

Both the benchmarks and frameworks put forth by the American Association for the Advancement of Science (1993) and National Research Council (1996, 2011) emphasize classroom strategies for both teaching and assessment that may not match with the beliefs that science teachers hold and enact in the classroom. As such, the inquiry reform mandate could present a challenge to each of the components of beliefs, all of which may be entrenched in both practice and self-identity (Cross \& Hong, 2009; Chinn \& Brewer, 1993). This may be one of the reasons why reform mandates do not always result in classroom-level change.

\section{Research Questions}

In the decade since the first publication of the National Science Education Standards documents (National Research Council, 1996), many science education stakeholders have worked to implement inquiry-based instruction in K-12 classrooms. However, we still cannot say that the goal of these reform mandates has been successfully achieved (Anderson \& Mitchener, 1994; Crawford, 2007; Fullan \& Miles, 1992; Sunal \& Wright, 2006; Wee, Shepardson, Fast, \& Harbor, 2007). Substantial numbers of teachers are experiencing difficulty in implementing inquiry-based instruction in their classrooms, and early career teachers who may not have enough experience and ability to take on the myriad of roles and demands are not the exception. Thus, this study 
attempts to explore how science teachers - especially early career teachers - interact with the reform mandate and to understand why they do not implement inquiry-based teaching in their classrooms. Given the importance of teachers' beliefs and identity in relation to their teaching practices, this study proposes the following research questions: (1) How do early career science teachers perceive and experience inquiry-based instruction?, (2) How are their beliefs matched with the underlying assumptions of inquiry-based instruction?, and (3) How are the science teachers' identities related to their school and classroom context where the reform agenda is translated into day-to-day routines and structures?

\section{Methods}

The nature of the study demands a qualitative approach in order to explore and understand science teachers' teaching practices, beliefs and identity in the context of reforms in Science Education. The open-ended nature of the qualitative approach allows participants to provide answers from their own perspectives without feeling restricted by the predetermined structure (Bogdan \& Biklen, 1982; Patton, 2002). In order to understand participants' own perspectives and experiences, an attempt was made to set aside or "bracket" the researcher's preconceived ideas so the view of the science teachers would be at the center of the study (van Manen, 1990).

\subsection{Participants}

Participants for this study included twelve beginning science teachers who are teaching in the Southeastern State in the U.S. The participants were graduated from the Secondary Science Teacher Certificate Program at a large Southeastern University in the U.S. Using criterion sampling strategy (Creswell, 2007), recruitment mails were sent to 308 individuals who graduated within three years and who were also listed in the alumni foundation data. Thirty individuals responded, and twelve of them were currently teaching. The twelve participants' background information is listed in Table 1.

\section{Table 1}

Participants' background information

\begin{tabular}{lcccc}
\hline \multicolumn{1}{c}{ Pseudonym } & Gender & Age & Number of years taught & Grade level \& Subject matter \\
\hline Bryan & M & 23 & 2 & $9^{\text {th }}$, Physical Science \\
Andrew & M & 28 & 5 & $10^{\text {th }}$, Biology \\
Calvin & M & 26 & 1.5 & $9^{\text {th }}$, Physical Science \\
Debbie & F & 30 & 2 & $8^{\text {th }}$, Physical Science \\
Mason & M & 26 & 2.5 & $9^{\text {th }}$, Biology \\
Danielle & F & 40 & 5 & $8^{\text {th }}$, Physical Science \\
Beck & M & 28 & 3 & $8^{\text {th }}$, Physical Science \\
Karen & F & 31 & 1 & $9^{\text {th }}$, Physical Science \\
Bailey & F & 24 & 3 & $9^{\text {th }}$, Biology \\
Ben & M & 23 & 2 & $10^{\text {th }}$, Biology \\
Christian & M & 31 & 5 & $11^{\text {th }}$, Physics \\
Diana & F & 30 & 2 & $8^{\text {th }}$, Physical Science \\
\hline
\end{tabular}

\subsection{Data Collection}

Data were collected using face-to-face, semi-structured interviews. Core interview questions were pre-developed based on the research questions, and probes were also used to further explore participants' views and thoughts. Sample interview questions include: "What are your thoughts on inquiry-based instruction?" and "How has your perception of yourself as a teacher changed in the light of inquiry-based reform initiatives?" Each interview lasted for about forty-five minutes to one and a half hours. All interviews were audio-taped and transcribed in verbatim.

\subsection{Data Analysis}


The data were analyzed inductively to find common themes and patterns across participants. First, each transcript was read thoroughly, and all responses relevant to the phenomenon of interest were noted on the transcript. Initial interview questions served as major categories, and we also developed a coding list as patterns emerged from the data (LeCompte \& Preissle, 1993). The major coding categories were formulated into meanings, which were represented as themes (Bogdan \& Biklen, 1982; Strauss \& Corbin, 1990). After the codes were constructed, the data were examined for patterns across all participants. Through this iterative, ongoing analysis, these preliminary categories were gradually modified, replaced, and refined. Once the themes were generated, the data were deductively tested by examining deviant narratives.

In order to enhance trustworthiness of this study, we have employed member checking, negative case analysis, reflective journal writing, and researcher triangulation. We sent out interview transcripts along with our tentative interpretations to the participants to check for accuracy and plausibility (Patton, 2002). After developing initial code list and themes, we searched for negative cases in order to recognize the boundary of the patterns and to incorporate these boundaries into explanations and interpretations (LeCompte \& Preissle, 1993). Also, we wrote reflective journals throughout the research process, so that our thoughts, insights, and feelings become visible, conscious, and open for inspection. This process contributed to increase the transparency of the research process (Denzin, 1994). Finally, in order to ensure inter-coder agreement, two researchers coded the same transcripts independently, and then compared to check their level of agreement. Overall, the agreement rate was over $80 \%$.

\section{Findings}

In order to understand what influences the success of reform implementation, we started this inquiry by asking about teachers' perceptions, experiences, and views regarding the goal of science teaching and inquiry-based instruction.

Participants' views about the goals of science education were separated into two statements that were related. The first goal category is related to promoting scientific thinking and science knowledge, so that the second goal of aiding students to become inquisitive citizens capable of using science for a healthier society could be accomplished. The comments of Beck, an $8^{\text {th }}$ grade physical science teacher, well-represented this theme.

I think that the goal is kids being able to think better and if you want to say that's thinking like the scientific method or thinking critically however one would say it, that's kind of what I think. They could think well enough so they can criticize and analyze. They can then transfer and continue and become lifelong learners.

Interestingly, these perceptions quite accurately reflect the concept of Scientific Literacy suggested by National Science Education Standards (National Research Council, 1996, 2011) and Benchmarks for Science Literacy (American Association for the Advancement of Science, 1993). Scientific Literacy is defined by the NSES as follows: Scientific literacy is the knowledge and understanding of scientific concepts and processes required for personal decision making, participation in civic and cultural affairs, and economic productivity.... Scientific literacy means that a person can ask, find, or determine answers to questions derived from curiosity and about everyday experiences. It means that a person has the ability to describe, explain and predict natural phenomena (p. 22).

While researchers have argued that this definition, as well as other aspects of the reform documents, are open to interpretation (Crawford, 2007), we view that the goal of the reform is for students to develop knowledge of the substantive content and processes of science in order to better understand the world around them, and to identify scientific issues underlying national and local decisions.

Participants in our study showed that their goals for science education are well-aligned with those of the reform documents; however, following interview responses indicated that they are still not devoting the majority 
of their teaching time to inquiry learning. This is also reflected in the findings from several research studies which have documented that the implementation of reform initiatives has not been successful at both local and nationwide levels (Chiapetta \& Adams, 2000; Crawford, 2007; Marshall, Horton, Igo, \& Switzer, 2009; Minstrell $\&$ van Zee, 2000). While, these studies acknowledge the difficulties in defining what successful implementation might look like, there remain two main questions: Where does the problem with implementation lie? Why does the apparent agreement between the goal of the reform agenda and the teachers' description of the goals of their own science teaching not lead to the successful implementation of the reform mandates?

In order to answer these questions, we first attempted to examine how teachers perceive and understand the reform mandates, and how they conduct instruction in keeping with the reform agenda.

\subsection{Perceptions and Understanding of Reform Standards}

In order to further explore these phenomena, we asked the early career teachers in our study how they both perceived and understood the content and process of inquiry-based instruction as suggested by the NSES. Regarding what they think inquiry-based instruction is and how they view it, the majority of the participants surprisingly revealed superficial understandings of the reform agenda or distorted information. It was salient that our participants implicitly equated inquiry-based learning with having lab activities or "getting your hands dirty". In our interview data, ten out of twelve participants' answers were limited to a view of inquiry as consisting solely of lab activities, such as "letting [the students] design their own labs/activities all the time" and "doing major labs". Only two teachers (Diana \& Beck) described inquiry-based instruction as going beyond just the inclusion of lab activities. For example, in her interview responses, Diana described how many of her cohorts misunderstood inquiry: "The way a lot of students in my cohort interpret it was complete hands-on, always a lab, always you're messing with something getting your hands dirty, and I don't agree with that." This contrasted sharply with her own view of inquiry which better reflected those of the reform mandated:

I think inquiry is when you are building your own knowledge based on your own explorations. My class is very much based on the Socratic Method. ... [I ask students] 'Okay, what does that mean?' That's inquiry, too, because they are building their own knowledge.

Within the inquiry-based reform mandates initiated with the publication of the NSES, competencies described as necessary for carrying out scientific inquiry included identifying and posing questions, designing and conducting investigations, analyzing data and evidence, using models and explanations, and communicating findings (National Research Council, 1996, 2011). In addition, Project 2061 more specifically listed instructional recommendations for teachers including: start with questions about nature, engage students actively, concentrate on the collection and use of evidence, provide historical perspectives, insist on clear expression, use a team approach, do not separate knowledge from finding out, and deemphasize the memorization of technical vocabulary. Even though multiple modes and patterns of inquiry-based instruction were suggested by the foundational documents cited above, many teachers in our data understand these criteria for inquiry as being met by unidimensional lab activities.

\subsection{Conducting Instruction in Keeping with Reform}

Given this understanding about teachers' perception of inquiry-based instruction, we further explored how teachers conduct instruction in their classroom. Not surprisingly, we found a matching pattern between teachers' perception and understanding of inquiry-based instruction and their teaching practice. The two teachers (Diana and Beck) who shared a similar perception that inquiry-based instruction is more than just having lab activities reported the largest apportionment $(90 \%-95 \%)$ of instructional time to inquiry. They noted that inquiry-based instruction is something to be infused in almost every lesson. For example, Beck described his use of video/movies as a component of his instruction. In order to emphasize the inquiry aspect of his instruction, he stops the video and engages students in discussions around claims that are made. He uses this as an example of 
how he infuses inquiry into all aspects of teaching and thus can claim that "I probably use it [inquiry] a lot... probably ninety percent would be a safe [estimate]."

In contrast, the remainder of the teachers, most of whom were identified as having a limited understanding of inquiry-based learning (i.e., consisting only of lab-activities), reported relatively low percentages of time devoted to inquiry $(10 \%-50 \%)$. Their answers tend to be focused on how many labs or hands-on activities they do. For instance, Mason and Danielle stated respectively, "I don't do it as much as I would like to do...I would say some of my labs are inquiry-based.", and "Probably about, um, honestly $30-40 \% \ldots$ because to prepare a lab or something for them takes a lot longer than opening a book and giving a handout." Her response shows a dichotomous perception about teaching science; having lab activities, which is equivalent to inquiry teaching in her perspective vs. teacher-centered instructional strategies, which she does not perceive as possible ways to incorporate inquiry. Additionally, in discussing reasons for not engaging in more inquiry activities, many of the teachers cited time constraints and limited material resources as hindrances for managing labs well. The beliefs that any inquiry classroom activity requires "labs" and "stuff" may also serve as confirmatory evidence of their narrow view of inquiry.

These differences showed that the way teachers conduct instruction is closely tied with how they perceive and understand the inquiry-based instruction. In order to further explore the underpinnings of these different perception and understanding, we focused on teachers' beliefs and identity in relation to an inquiry-based reform mandate.

\subsection{Teacher Beliefs and Their Relation to Inquiry-Based Instruction}

In order to explore if teachers' beliefs are aligned with the underlying assumption of inquiry-based instruction, we asked about teachers' beliefs about science knowledge and effective ways of teaching and learning science.

Unlike their shallow understanding about inquiry-based instruction, the majority of the participants shared much deeper constructivist beliefs that science knowledge should be empirically based, is subject to change, and involves observation and inferences. For instance, Karen stated, "Well, instead of students just reading what other people have done, they are if they actually recreate it [science knowledge] themselves then because more of their brain is being used because they're thinking about it and they are uh, actually seeing it and some things they're actually smelling, and it can related to um, more of their real life, then it, it sticks better with them that, that is what science is." Calvin also well-represented this view when he said, "Especially teaching science, you should encourage the kids to inquire. The best way [to learn science], of course, is through experimentation, through experience."

Additionally, participants acknowledged the importance of learners' active role in constructing knowledge and having interests in learning science. Calvin stated, "As a teacher, I think that should be your primary responsibility is to facilitate learning and sort of give the kids the direction they need to go in." Danielle mirrored this belief when she commented, "It should be fun. I think having an interest, um, provides some impetus for them to, to gain uh, some knowledge and understanding pretty much on their own."

This finding asks us an emerging question: "Why do these participants still have narrow view about implementing inquiry-based instruction, while they have constructivist beliefs on teaching and learning science, which are well-aligned with the underpinning idea of inquiry-based reform effort?" Keeping in mind this question, we continued to explore their professional identity in relation to implementing reform effort.

\subsection{Teachers' Professional Identity and Its Relation to Inquiry-Based Instruction}

Teachers' identity is established and maintained through the interaction with social situations and negotiation of roles within particular contexts. Thus, in order to understand teachers' sense of self developed 
through interaction with the environment, we explored how school and classroom contexts mediate the reform agenda with regard to instructional practices of individual teachers and how teachers' agency and autonomy are practiced in the process of communication and translating reform mandate into their teaching practices.

School context and teacher agency - One of the interesting findings was the way inquiry-based initiatives were presented and supported in the school. For instance, Beck stated:

They [my school] limit us on the amount of copies we can make, because they don't want us doing work sheets or anything. (Laugh)... I think our school is onboard, I mean even [in terms of] the textbook they picked out for us.

For Beck, being “onboard" was his way of confirming his school's support for inquiry teaching. But, he also felt restricted because his school tried to push inquiry-based instruction by limiting resources and making major decisions, such as textbook selection, at the school level. Although these postures by the school's administration did not have a direct negative impact on Beck, whose beliefs about teaching science were aligned with those of the school's administration, he acknowledged that they did make it more difficult for other teachers. For instance, he stated during one interview: "Most teachers in our, um school system do not like these new textbooks, because they are inquiry-based." His statement provides insight regarding how schools regulate and enforce their larger goals and limits the autonomy of teachers, which create tensions between individual teachers' agency and school-level efforts to implement reform mandates.

Several teachers in our data showed how much they valued individual teachers' agency. For instance, Christian and Karen stated respectively, "I don't think that the school should have to tell us what to teach in regard to reform standards. I have not had an administrator say 'you must teach the state level standards', probably because they don't think that I am an idiot.", and "I think it's [implementing reform mandates] probably up to me to try to keep up to date or even to inform the people in charge of what you are doing." These responses echo with what Day (2002) noted in regard to teacher autonomy. When schools mediate the reform agenda to individual teachers in a restrictive and oppressive way, it can (1) threaten teachers' sense of agency, (2) implicitly encourage teachers to comply uncritically, (3) challenge teachers' substantive identity, (4) reduce the time teachers have to connect with, care for and attend to the needs of individual students, or (5) diminish teachers' sense of motivation, efficacy, and job satisfaction. As we saw above, the way Beck's school supports inquiry-based instruction (i.e., limiting the amount of copies and selecting textbook at the school level) has the potential danger of constraining teachers from engaging in more personalized inquiry-based instruction.

Classroom context and teachers' emotions - The teachers who participated in this study consistently mentioned several sources of difficulties of implementing inquiry-based instruction, which are associated with unpleasant emotional experiences. For example, Andrew talked about "lack of time" as a hindrance of his effort to implement inquiry-based instruction and his stress related to that:

On the block schedule teaching physical science or biology, you're on a time frame and most inquiry labs, to the best of my knowledge and what I've seen, take about twice as long as a regular lab. The time constraints are really tough to do a lot of inquiry. It can wear you down, and puts stress on you. It's a taxing job.

Other teachers who teach on a regular schedule also consistently mentioned that they do not have enough time to implement inquiry labs, and thus they experience unpleasant emotions such as anxiety and stress. In particular, given their beliefs that doing lab activities is the only way to implement inquiry-based instruction, the time constraints serve as a major source of stress and frustration.

The second major source related to the difficulties inherent in inquiry instruction was strongly related to classroom management. Both groups of teachers who have a more open view of inquiry (Diana and Beck) and a narrow view of inquiry (Rest of the participants) mentioned the challenge of optimizing students' learning from 
inquiry-based instruction due to students' lack of cognitive ability, lack of effort, and disruptive behaviors. For example, Andrew stated his views in this way:

It's a continuum... my higher-level students, I will give them the basics and a list of materials. They are to come up with the experiment and run it. If you do that with lower-level students, they might make a bomb. It's really not funny. It's not a joke. Not only will they not end up where you want them to end up, most times they're going to whine and cry about it and shut down and not do it.

Bailey, a $9^{\text {th }}$ grade biology teacher, added his emotional experience; "It can also be very frustrating for the students and the teachers when the students do not arrive at an answer that is correct." Calvin echoed this frustration:

This can be frustrating when you're working with kids and they don't even want to try anymore. I've had kids that you work on the whole semester and they still end up letting you down in the end. That really gets me going is the kids being lazy and thinking that they can't do it, or not doing their homework.

Students' disruptive behaviors are also a primary barrier to the implementation of inquiry-based learning. Several teachers mentioned that "some kids can't deal with that type of freedom.", and it's difficult to "get kids to work in groups" or "manage kids' behavior". They often reported this classroom management issue in relation to their frustration, anger, or stress.

As such, the way teachers implement reform-based practices and their emotional experiences are significantly influenced by classroom transactions and the interaction with students. As Kelchterman (1993, 1996) and Zembylas (2003, 2004) noted previously, teachers' sense of self and emotions are embedded in a context of power relations. Thus, when teachers lose control over important instructional issues due to these barriers, and feel underestimated or vulnerable, they are more likely to develop a negative perception of self and unpleasant emotions such as powerlessness, frustration, and anger. These findings provide us insight that teachers' effort to implement reform mandates are often faced with barriers at a classroom level, and it often leads teachers feel frustrated, which consequently undermines their sense of self as a teacher.

\section{Discussions and Implications}

The reform agenda changes the environment of the school culture in many ways, and these changes affect students, teachers, and administrators under increasing pressure to meet district, state, and national standards. Intended or not, these reforms have influenced teachers' teaching practices, which cannot be separated from their beliefs and identity as a teacher (Cross \& Hong, 2009; Day, 2002; Eick \& Reed, 2002; Lasky, 2005). The majority of teachers who participated in this study showed that their own view of teaching science quite closely reflects the goal of the standards reform. However, even if teachers' goals are congruent with those recommended by the reform agenda, the actual implementation in the classroom has, for many of our participants, not been as successful. Teachers often shared their constrained view of inquiry-based learning that is limited to labs or hands-on activities while overlooking other aspects of the approach, such as encouraging questioning within teacher-cantered segments of instruction and non-experiment-based research skills. While lab-based activities are an important aspect of inquiry-based learning, teachers' view of inquiry-based learning in this restricted sense can be frustrated by the reform mandate as it is not practical for everyday application in the classroom.

The findings of this study also showed that although teachers have shallow understanding about inquiry strategies, their beliefs about teaching science are well-aligned with the assumptions of inquiry-oriented instruction. The current study contributes in providing some insight into this missing link between beliefs and practice. Although teachers' beliefs are aligned with the underpinning of inquiry-based instruction, their teaching 
practices seem to be more heavily influenced by classroom or school environment, which is not necessarily conducive for inquiry teaching. The ill-structured nature of classroom environment, uncontrollable factors, and complex interactions in the classroom hinder teachers from making pedagogical decisions and performing instructional tasks based on their beliefs. In particular, participants in the current study talked about lack of time to plan and implement inquiry teaching, students' low cognitive abilities, students' lack of effort, and students' disruptive behaviors as major contributing factors to influence their classroom transaction.

When teachers recognize and face these hindrances, they often experience unpleasant emotions such as frustration, anger, and anxiety. These emotions are elicited because of the struggle teachers have with the limits of their teaching impact on students' learning, and also teachers' lack of power or control in implementing teaching in the way they intended. As several researchers have noted, when teachers experience unpleasant emotions such as frustration and discomfort, it can have the effect of threatening their identity as teachers (e.g., Schutz, Cross, Hong, \& Osbon, 2007; Kelchtermans, 1996). The impaired sense of self as a teacher and feelings of powerlessness and vulnerability may prevent them from exerting effort to translate their beliefs into classroom teaching, or from changing their beliefs and adapting their teaching practices. As our data showed, oftentimes teachers resort to a specific teaching model or action-oriented strategies, such as having lab activities, instead of incorporating scientific investigation and reasoning skills through diverse approaches such as posing questions, facilitating and guiding students' critical thinking, and emphasizing procedures to answer questions.

Findings from this study also provided insight that it is important to see the agency of teachers as a necessary part of the success of reform. Fullan (2001) has written criticism based on the idea that "most strategies for reform focus on structure, formal requirements, and event-based activities involving, for example, professional development sessions. They do not struggle directly with existing cultures and which new values and practices may be required (p. 34)." As such, what is important for successful reform implementation is to acknowledge teachers' agency and to support individual teachers' autonomy and authority both in their classroom and in dialogues on reform, so that they can actively interpret meanings around them, negotiate roles within the reform context, and develop a sense of self as a teacher. In line with this idea, Hargreaves (2001) has also noted the importance of teacher agency, which functions as motivation to carry these changes through and to persist over the long term.

In particular, we need to consider early career teachers who have not yet developed skill sets and stability in the career. If early career teachers repeatedly experience frustration, stress, and failure to meet the standard, it may leave a negative imprint on them in regard to the teaching profession. As several researchers have reported (Ashton, 1985; Evans \& Tribble, 1986), early career teachers who develop a negative perception about themselves as teachers are especially vulnerable to stressful classroom realities and are therefore at risk for professional development such as teacher dropout, lack of motivation, and inefficiency. We believe that the current high attrition rate of early career teachers reflects this point to some extent. In relation to this, Kelchtermans' (1996) ideas provided meaningful suggestions for school administrators and policy makers. Kelchtermans claimed that teachers' sense of vulnerability is shaped by experiences of power and powerlessness. Thus, it is important to acknowledge teachers' agency and empower them especially in their first few years in teaching profession, so that they can have the opportunity to be actively involved in decision making and problem solving in school, which in turn makes them feel less vulnerable and their professional identity less threatened. If teachers' professional identity is threatened, it inevitably influences their beliefs and emotions in a negative way (O'Connor, 2008). When this happens, we cannot really expect meaningful changes at the classroom level, which is the most important and necessary point of change.

This study, although exploratory in nature, adds to the knowledge of teachers' perception and implementation of reform mandates in relation to their beliefs and professional identity. The findings of this study are expected to guide future directions for school administrators and policy makers, so that more meaningful change can be made at the classroom level. 


\section{References}

Allport, G. W. (1955). Becoming. New Haven, CT: Yale University Press.

American Association for the Advancement of Science. (1993). Benchmarks for science literacy. New York: Oxford University Press.

Anderson, R. D. (2002). Reforming science teaching: What research says about inquiry. Journal of Science Teacher Education, 13(1), 1-12. http://dx.doi.org/10.1023/A:1015171124982

Anderson, R. D., \& Mitchener, C. P. (1994). Research on science teacher education. In D. Gabel (Ed.), Handbook of research on science teaching and learning (pp. 3-44). New York: Macmillan.

Ashton, P. (1985). Motivation and teachers' sense of efficacy. In C. Ames \& R. Ames (Eds.), Research on Motivation in education: The classroom milieu (Vol. 2, pp. 141-174). Orlando, FL: Academic Press.

Bogdan, R. C., \& Biklen, S. K. (1982). Qualitative research for education: An introduction to theory and methods. Boston: Allyn and Bacon, Inc.

Bryan, L. A. (2003). Nestedness of beliefs: Examining a prospective elementary teacher's belief system about science teaching and learning. Journal of Research in Science Teaching, 40(9), 835-868. http://dx.doi.org/10.1002/tea.10113

Chiapetta, E., \& Adams, A. (2000). Towards a conception of teaching science and inquiry - The place of content and process. A paper presented at the Annual Meeting of the National Association for research in science teaching. New Orleans.

Chinn, C. A., \& Brewer, W. F. (1993). The role of anomalous data in knowledge acquisition: A theoretical framework and implications for science instruction. Review of Educational Research, 63(1), 1-49. http://dx.doi.org/10.3102/00346543063001001

Cooley, C. H. (1902). Human nature and social order, New York: Scribner's.

Cooper, K., \& Olson, M. (1996). The multiple 'I's of teacher identity. In M. Kompf, D. Dworet, \& R. Boak (Eds.), Changing research and practice (pp. 78-89). London: Falmer Press.

Crawford, B. (2007). Learning to teach science as inquiry in the rough and tumble of practice. Journal of Research in Science Teaching, 44(4), 613-642. http://dx.doi.org/10.1002/tea.20157

Creswell, J. W. (2007). Qualitative inquiry and research method: Choosing among five approaches (2nd. ed.). Thousand Oaks, CA: Sage.

Cross, D. I., \& Hong. J. Y. (2009). Beliefs and professional identity: Critical constructs in examining the impact of reform on the emotional experiences of teachers. In P. A. Schutz \& M. Zembylas (Eds.), Advances in teacher emotion research: The impact on teachers' lives (pp. 273-296). New York, NY: Springer. http://dx.doi.org/10.1007/978-1-4419-0564-2_14

Day, C. (2002). School reform and transitions in teacher professionalism and identity. International Journal of Educational Research, 37, 677-692. http://dx.doi.org/10.1016/S0883-0355(03)00065-X

Denzin, N. K. (1994). The art and politics of interpretation. In N. K. Denzin \& Y. S. Lincoln (Eds.), Handbook of qualitative research (pp. 500-515). Thousand Oaks, CA: Sage.

Eick, C. J., \& Reed, C. J. (2002). What makes an inquiry-oriented science teacher? The influence of learning histories on student role identity and practice. Science Teacher Education, 86, 401-416.

Ernest, P. (1989a). The knowledge, beliefs and attitudes of the mathematics teacher: A model. Journal of Education for Teaching, 15(1), 13-33. http://dx.doi.org/10.1080/0260747890150102

Ernest, P. (1989b). The impact of beliefs on the teaching of mathematics. Paper presented at the ICME IV, Budapest, Hungary.

Evans, E. D., \& Tribble, M. (1986). Perceived teaching problems, self-efficacy, and commitment to teaching among preservice teachers. Journal of Educational Research, 80(2), 81-85. http://dx.doi.org/10.1080/00220671.1986.10885728

Fogel, A. (2001). A relational perspective on the self and emotions. In H. A. Bosma \& E. S. Kunnen (Eds.), Identity and emotion: Development through self-organization (pp. 93-114). Cambridge: Cambridge University Press. http://dx.doi.org/10.1017/CBO9780511598425.009

Frijda, N. H. (2001). The self and emotions. In H. A. Bosma \& E. S. Kunnen (Eds), Identity and emotion: 
Science teachers' perception and implementation of inquiry-based reform initiatives

development through self-organization (pp.39 - 57). Paris: Cambridge University Press. http://dx.doi.org/10.1017/CBO9780511598425.005

Fullan, M. (2001). The New Meaning of Educational Change. 3rd edition. New York: Teachers College Press.

Fullan, M. G., \& Miles, M. B. (1992). Getting reform right: What works and what doesn't. Phi Delta Kappan, 73, 745-752.

Giddens, A. (1979). Central problems in social theory: Action, structure and contradiction in social analysis. Berkeley, CA: University of California Press.

Gregoire, M. (2003). Is it a challenge or a threat? A dual process model of teachers' cognition and appraisal processes during conceptual change. Educational Psychology Review, 15, 147-179. http://dx.doi.org/10.1023/A:1023477131081

Hargreaves, A. (2001). Learning to change: Teaching beyond subjects and standards. San Francisco, CA: Jossey-Bass.

Harter, S. (1998). The development of self-representations. In N. Eisenberg (Ed.) Handbook of child psychology, $5^{\text {th }}$ ed., vol. 3, Social, emotional, and personality development. pp. 553-617. New York: Wiley.

Hermans, H. \& Hermans-Jansen, E. (2001). Affective processes in a multivoiced self. In H. A. Bosma \& E. S. Kunnen (Eds.), Identity and emotion: development through self-organization (pp.120-150). Paris: Cambridge University Press. http://dx.doi.org/10.1017/CBO9780511598425.011

Ibrahim, A. S., Al-Kaabi, A., \& El-Zaatari, W. (2013). Teacher resistance to educational change in the United Arab Emirates. International Journal of Research Studies in Education, 2(3), 25-36. http://dx.doi.org/10.5861/ijrse.2013.254

Johnson, K. A. (2003). 'Every experience is a moving force': Identity and growth through mentoring. Teaching and Teacher Education, 19(8), 787-800. http://dx.doi.org/10.1016/j.tate.2003.06.003

Kagan, D. (1992). Implications of research on teacher belief. Educational Psychologist, 27(1), 65-90. http://dx.doi.org/10.1207/s15326985ep2701_6

Kang, N. (2008). Learning to teach science: Personal epistemologies, teaching goals, and practices of teaching. Teaching and Teacher Education: An International Journal of Research and Studies, 24(2), 478-498. http://dx.doi.org/10.1016/j.tate.2007.01.002

Kang, N., \& Wallace, C.S. (2004). Secondary science teachers' use of laboratory activities: Linking epistemological beliefs, goals, and practices. Science Education, 89(1), 140-165. http://dx.doi.org/10.1002/sce.20013

Kelchtermans, G. (1993). Getting the story, understanding the lives: From career stories to teachers' professional development. Teaching and Teacher Education, 9(5-6), 443-456. http://dx.doi.org/10.1016/0742-051X(93)90029-G

Kelchtermans, G. (1996). Teacher vulnerability: Understanding its moral and political roots. Cambridge Journal of Education, 26(3), 307-323. http://dx.doi.org/10.1080/0305764960260302

Korthagen, F. A. J. (2004). In search of the essence of a good teacher: Towards a more holistic approach in teacher education. Teaching and Teacher Education, 20(1), 77-97.

http://dx.doi.org/10.1016/j.tate.2003.10.002

Lasky, S. (2005). A sociocultural approach to understanding teacher identity, agency and professional vulnerability in a context of secondary school reform. Teaching \& Teacher Education: An International Journal of Research and Studies, 21(8), 899-916. http://dx.doi.org/10.1016/j.tate.2005.06.003

Le Compte, M. D., \& Preissle, J. (1993). Considerations on selecting a research design. In Ethnography and Qualitative design in educational research (2nd ed., pp. 30-55). New York: Academic Press.

Lederman, N. G. (1999). Teachers' understanding of the nature of science and classroom practice: Factors that facilitate or impede the relationship. Journal of Research in Science Teaching, 36(8), 916-929. http://dx.doi.org/10.1002/(SICI)1098-2736(199910)36:8<916::AID-TEA2>3.0.CO;2-A

Lederman, N. G., \& Zeidler, D. L. (1987). Science teachers' conceptions of the nature of science: Do they really influence teaching behavior? Science Education, 71(5), 721-734. http://dx.doi.org/10.1002/sce.3730710509

Lemke, J. L. (2003, April). Identity, development, and desire: Critical questions. Paper presented at the meeting 
of the American Educational Research Association, Chicago, IL. Available from http://www.personal.umich.edu/ jaylemke/papers/Identity/identity_area_2003.htm

Lofty, J. (2006). Quiet wisdom: Teachers in the United States and England talk about standards, practice and professionalism. New York: Lang Publishing, Inc.

Lotter, C., Harwood, W. S., \& Bonner, J. J. (2007). The influence of core teaching conceptions on teachers' use of inquiry teaching practices. Journal of Research in Science Teaching, 44(9), 1318-1347. http://dx.doi.org/10.1002/tea.20191

Marshall, J. C., Horton, R., Igo, B. L., \& Switzer, D. M. (2009). K-12 science and mathematics teachers' beliefs about and use of inquiry in the classroom. International Journal of Science and Mathematics Education, 7, 575-596. http://dx.doi.org/10.1007/s10763-007-9122-7

Mehan, H., Villanueva, I., Hubbard, L., \& Lintz, A. (1996). Constructing school success: The consequences of untracking low achieving students. Cambridge: Cambridge University Press. http://dx.doi.org/10.1017/CBO9781139174664

Minner, D., Levy, A., \& Century, J. (2010). Inquiry-based science instruction - what is it and does it matter? Results from a research synthesis years 1984 to 2002. Journal of Research in Science Teaching, 47(4), 474-496. http://dx.doi.org/10.1002/tea.20347

Minstrell, J., \& van Zee, E.H. (Eds.). (2000). Inquiring into inquiry learning and teaching in science. Washington, DC: American Association for the Advancement of Science.

National Research Council (1996). National science education standards. Washington, DC: National Academy Press.

National Research Council. (2011). A Framework for K-12 Science Education: Practices, Crosscutting Concepts, and Core Ideas. Committee on a Conceptual Framework for New K-12 Science Education Standards. Board on Science Education, Division of Behavioral and Social Sciences and Education. Washington, DC: The National Academies Press.

O'Connor, K. (2008). "You choose to care": Teachers' emotions and professional identity. Teaching and Teacher Education, 24, 117-126. http://dx.doi.org/10.1016/j.tate.2006.11.008

Pajares, M. F. (1992). Teachers' beliefs and educational research: Cleaning up a messy construct. Review of Educational Research, 62(3), 307-332. http://dx.doi.org/10.3102/00346543062003307

Park, S. H., \& Oliver, J. S. (2008). Reconceptualization of Pedagogical Content Knowledge (PCK): PCK as a Conceptual Tool to Understand Teachers as Professionals. Research in Science Education, 38(3), 261-284. http://dx.doi.org/10.1007/s11165-007-9049-6

Patton, M. Q. (2002). Qualitative research and evaluation methods (3rd ed.). Thousand Oaks, Calif.: Sage Publications.

Roehrig, G.H. \& Kruse, R.A. (2010). The role of teachers' beliefs and knowledge in the adoption of a reform-based curriculum. School Science and Mathematics, 105(8), 412-422. http://dx.doi.org/10.1111/j.1949-8594.2005.tb18061.x

Romanowski, M. H. \& Amatullah, T. (2014). The impact of Qatar national professional standards: Teachers' perspectives. International Journal of Research Studies in Education, 3(2), 97-114. http://dx.doi.org/10.5861/ijrse.2014.664

Schmidt, M., \& Datnow, A. (2005). Teachers' sense-making about comprehensive school reform: The influence of emotions. Teaching and Teacher Education, 21, 949-965. http://dx.doi.org/10.1016/j.tate.2005.06.006

Schutz, P. A., Cross, D. I., Hong, J. Y., \& Osbon, J. N. (2007). Teacher understandings, thoughts, and beliefs about emotions in the classroom. In P. A. Schutz \& R. Pekrun (Eds.), Emotions in education (pp. 215-233). San Diego, CA: Elsevier Inc. http://dx.doi.org/10.1016/B978-012372545-5/50014-9

Sloan, K. (2000). Teacher Agency and the TAAS: Maintaining the Ability to "Act Otherwise." Paper presented at the Annual Meeting of the American Educational Research Association, New Orleans, LA, April.

Strauss, A., \& Corbin, J. M. (1990). Basics of qualitative research: Grounded theory procedures and techniques. Sage Publications, Inc.

Sullivan, F. (2008). Robotics and science literacy: thinking skills, science process skills and systems 
Science teachers' perception and implementation of inquiry-based reform initiatives

understanding. Journal of Research in Science Teaching, 45(3), 373-394.

http://dx.doi.org/10.1002/tea.20238

Sunal, D. W., \& Wright, E. L. (Eds.) (2006). Research in science education: Volume 2. The impact of state and national standards in K-12 science teaching. Charlotte, NC: Information Age Publishing.

Tobin, K., \& McRobbie, C. J. (1997). Beliefs about the nature of science and the enacted science curriculum. Science and Education, 6, 355-371. http://dx.doi.org/10.1023/A:1008600132359

Torff, B., \& Warburton, E. (2005). Assessment of teachers' beliefs about classroom use of critical-thinking activities. Educational and Psychological Measurement, 65, 155-179. http://dx.doi.org/10.1177/0013164404267281

Trumbull, D. J., Scarano, G., \& Bonney, R. (2006). Relations among two teachers' practices and beliefs, conceptualizations of the nature of science, and their implementation of student independence inquiry projects. International Journal of Science Education, 28(14), 1717-1750. http://dx.doi.org/10.1080/09500690600560928

Tsai, C. (2006). Teachers' scientific epistemological views: The coherence with instruction and students' views. Science Education, 91(2), 222-243. http://dx.doi.org/10.1002/sce.20175

Van den Berg, R. (2002). Teachers' meanings regarding educational practice. Review of Educational Research, 72(4), 577-625. http://dx.doi.org/10.3102/00346543072004577

Van Lier, L. (2007). Action-based teaching, autonomy and identity. Innovation in Language Learning and Teaching, 1(1), 46-65. http://dx.doi.org/10.2167/illt42.0

Van Manen, M. (1990). Researching lived experience: Human science for an action sensitive pedagogy. Albany, NY: State University of New York Press.

Van Veen, K., Sleegers, P., \& Van de Ven, P-H. (2005). One teacher's identity, emotions, and commitment to change: A case study into the cognitive-affective processes of a secondary school teacher in the context of reforms. Teaching and Teacher Education, 21, 917-934. http://dx.doi.org/10.1016/j.tate.2005.06.004

Water-Adams, S. (2006). The relationship between understanding of the nature of science and practice: The influence of teachers' beliefs about education, teaching and learning. International Journal of Science Education, 28(8), 919-944. http://dx.doi.org/10.1080/09500690500498351

Watson, C. (2006). Narratives of practice and the construction of identity in teaching. Teachers and Teaching: Theory and Practice, 12(5), 509-526. http://dx.doi.org/10.1080/13540600600832213

Wee, B., Shepardson, D., Fast, \& Harbor, J. (2007). Teaching and learning about inquiry: Insights and challenges in professional development. Journal of Science Teacher Education, 18, 63-89. http://dx.doi.org/10.1007/s10972-006-9031-6

Zembylas, M. (2003). Emotions and Teacher Identity: A poststructural perspective. Teachers and Teaching: Theory and Practice, 9(3), 213-238. http://dx.doi.org/10.1080/13540600309378

Zembylas, M. (2004). The emotional characteristics of teaching: An ethnographic study of one teacher. Teaching and Teacher Education, 20(2), 185-201. http://dx.doi.org/10.1016/j.tate.2003.09.008 
Hong, J., \& Vargas, P. 